\title{
RELIGIA JAKO RADYKALNE DĄŻENIE DO SENSU W LOGOTERAPII VIKTORA E. FRANKLA
}

\author{
„Nie muszę wierzyć w Boga, bo wiem, że jest”. \\ Carl Gustav Jung, Küstnacht 1960
}

\begin{abstract}
Streszczenie. Pytanie o sens jest centralnym pytaniem logoterapii Frankla. Życie człowieka polega na sensownym urzeczywistnianiu się i, w razie potrzeby, na przezwyciężaniu kryzysu sensu, któremu służy logoterapia jako metoda psychoterapeutyczna. Religia jest dla Frankla niczym innym, jak radykalnym dążeniem do sensu. Wiara w sens, leżąca u podstaw dążenia do sensu, pozwala człowiekowi nie tylko poszukiwać go w każdej sytuacji, ale także umożliwia przetrwanie w obliczu cierpienia i życiowej katastrofy. Życie sensowne daje ostatecznie człowiekowi poczucie spełnienia, niezależnie od tego, jaki czeka go dalszy los.
\end{abstract}

Słowa kluczowe: logoterapia, psychoterapia, Frankl, sens, religia, wiara

1. Transcendowanie jako otwarcie drogi do sensu. 2. Bóg jako możliwość przetrwania w krytycznych sytuacjach życiowych. 3. Religia jako wiara w sens. 4. Sumienie jako miejsce podejmowania sensownych decyzji, źródło poszukiwania sensu i przestrzeń rozmowy z Bogiem. 5. Ukryty Bóg jako możliwość stworzenia więzi religijnej. 6. Religia potrzebuje dynamiki wiary.

Gdy w dziejach zachodniego myślenia pojawiał się kryzys i szukano odradzających idei, zwracano się do greckich początków filozofii, $\mathrm{w}$ decydujący sposób ukształtowanych przez słowo logos. $Z$ przekazanych wypowiedzi ustalono, że logos oznacza: zdolności ducha, rozum, słowo, mowę, sens mowy, ogólną zasadę rozumności świata, całościowy sens rzeczywistości ${ }^{1}$. W obliczu kryzysu sensu, który dotyka człowieka naszych czasów, psychiatra i neurolog Viktor E. Frankl sięga po słowo logos tak, jak je rozumiano na początku filozofii: „Logos logoterapii jest rozumiany w dwojaki sposób: po pierwsze

1 Historisches Wörterbuch der Philosophie, red. von J. Ritter, K. Gründer, Band 5, Basel-Stuttgart 1980, 491-498. 
jako sens, a po drugie jako duch"2. Logo(s)terapia oznacza metodę psychoterapeutyczną, koncentrującą się na duchowym wymiarze, w którym człowiek poszukuje sensu. Logoterapia zajmuje się leczeniem ludzi dotkniętych nerwicami, obciążonych kryzysem sensu i uczy przyjmowania sensownej postawy w sytuacjach życiowych, zwłaszcza w sytuacjach, w których pojawia się cierpienie. Logoterapia szuka wskazującej na sens odpowiedzi na pytania, jakie stawia życie. W kontekście sensu życia człowieka pada również pytanie o Boga. Bóg w logoterapii jest możliwością przetrwania i przezwyciężenia kryzysu sensu i motywem budowania sensownego życia.

Franklowskie poszukiwanie Boga opiera się metodycznie na wskazaniu: „poznaj samego siebie” (gnothi seauton), które miłujący mądrość Grecy mogli przeczytać w Delfach - mieście przepowiedni - przed wejściem do świątyni poświęconej Apollowi. Frankl rozumie je nie jako poznanie i uznania granic swoich możliwości, ale w sensie rozpoznania możliwości przekraczania swoich granic. W samopoznaniu Frankl widzi drogę do odkrycia śladów prowadzących do Boga. Podobnie myślał Augustyn z Hippony: per ipsam animam meam ascendam ad illum, przez poznanie mojej duszy samej wznoszę się do Niego. O ile Augustyn przez poznanie siebie odkrywa swoją ograniczoność wobec nieskończonej wielkości Boga, a tym samym duchową niemoc, która potrzebuje wsparcia łaski, o tyle Frankl w poznaniu siebie natrafia na niezłomną siłę ducha (Trotzmacht des Geistes), dzięki której człowiek może oprzeć się kryzysowi sensu i sensownie ukształtować swoje życie w obecności Boga.

Frankla myślenie o Bogu nie jest psychologią religii, zajmującą się psychicznymi uwarunkowaniami religijnych przeżyć i zachowań, lecz logoteorią religii, która - posługując się analizą psychologiczną i analizą egzystencji - opisuje fenomen religijności, jaki jawi się w duchowym obszarze człowieka. Logoteoria religii Frankla kieruje

2 V.E. Frankl, Logotherapie und Existenzanalyse. Texte aus sechs Jahrzehnten, Weinheim und Basel 2010, 58. 
się obrazem człowieka bliskim egzystencjalno-fenomenologicznej (Pascal, Husserl, Scheler, Jaspers, Heidegger) tradycji filozoficznej i obrazem Boga podobnym do judeochrześcijańskiej tradycji religijnej. Chociaż Frankl krytycznie odnosi się do Freuda, jego obrazu człowieka i widzenia $\mathrm{w}$ religii zbiorowej nerwicy, to pozostaje w kręgu niektórych pojęciowych rozróżnień wypracowanych przez psychoanalizę. Dla psychoanalizy, nazywanej psychologią głębi, Frankl odkrywa przeciwwagę w postaci psychologii wyżyn, skupionej na dążeniu człowieka do sensu, ponad dążeniem do przyjemnoścỉ. Frankl zawsze mówił: „,miałem tylko dwóch mistrzów: Freuda i Heideggera”. Obaj nauczyli go patrzeć na człowieka bez jakiejkolwiek zasłony, na takiego, jaki jest. Podczas gdy Heidegger i Freud wskazują, jak bardzo człowiek jest podlegającą rozpadowi (Verfallen) i sterowaną nieuświadomionymi siłami popędowymi (Es - Kräfte), skończoną istotą, Frankl pokazuje, jak dalece człowiek może przezwyciężyć swoje psychiczne, dziedziczne i socjologiczne uwarunkowania, decydując się na sensowne życie.

\section{TRANSCENDOWANIE JAKO OTWARCIE DROGI DO SENSU}

W centrum myślenia religijnego Frankla stoi Transcendencja. „Osoba pojmuje siebie nie inaczej, jak przez Transcendencje". Filozofia rozumie przez Transcendencję: (1) to, co Absolutne, (2) transcendowanie ku temu, co Absolutne i (3) samo transcendowanie z niższego do

3 „Ukształtowano wyrażenie psychologia głębi (Tiefenpsychologie). Lecz gdzie pozostaje psychologia wyżyn (Höhenpsychologie), która włącza w swoje pole widzenia nie tylko wolę przyjemności, ale również wolę sensu? Musimy się zapytać, czy nie nastał czas by widzieć, także w obrębie psychoterapii, ludzką egzystencję nie tylko w jej głębokości, ale także w jej wysokości, aby nie tylko świadomie sięgać ponad stopień tego, co fizyczne, lecz także jeszcze ponad to, co psychiczne, włączając zasadniczo obszar tego, co duchowe." V.E. Frankl, Ärztliche Seelsorge. Grundlagen der Logotherapie und Existenzanalyse. Mit den Zehn Thesen über die Person, Bern 2015, 32.

4 V.E. Frankl, Ärztliche Seelsorge, dz. cyt., 339. 
wyższego bycia ${ }^{5}$ Transcendowanie oznacza przekraczanie (transcendere) granic. Przekraczanie granic nie jest naruszaniem granic, jak przekracza się granice dobrego smaku lub granice prawa, ani przekraczaniem w sensie przechodzenia przez granice państwa, ale otwierającym i wyzwalającym wychodzeniem poza ograniczenia, dotyczące bycia w świecie. Przez Transcendencję tradycja filozoficzna rozumie rzeczywistość wykraczającą poza doświadczenie świata. Transcendencja jest filozoficznym imieniem Boga. Filozofia posługuje się pojęciem Boga jako Transcendencji, które stoi ponad pojęciem Boga określonej religii. Bóg jest właśnie Bogiem dlatego, że jest Transcendencją: wychodzi poza wszelkie granice, nie pozwala nałożyć sobie żadnych ograniczeń i może wkroczyć w obszar każdych granic. Aby spotkać się z transcendentnym Bogiem, człowiek musi przekroczyć granice swojego świata. Kiedy człowiek usiłuje wymusić coś na Bogu lub wciągnąć Go w gry światowe, narusza Jego Transcendencję i naraża się na Jego wycofanie się. Frankl jest przekonany, że obrabowany z Transcendencji Bóg, który staje się jakąś tajemniczą energią przenikającą świat lub jakąs tajemną siłą obecną w człowieku, nie może być Bogiem człowieka poszukującego sensu, potrzebującego suwerennego, pozaświatowego Partnera. Rozumieć siebie przez Transcendencję znaczy: odkryć w sobie nieograniczone możliwości przekraczania siebie. Bóg nie jest dla człowieka konkurencją, z którą trzeba się zmierzyć lub której należy się poddać. Spotkanie $z$ transcendentnym Bogiem daje człowiekowi do zrozumienia, jak jest ograniczony, a jednocześnie pokazuje mu rozmiar rozwijania jego możliwości. Współczesny, nowoczesny człowiek szuka Transcendencji w sobie ${ }^{7}$. Wierzy w swoje boskie, niczym nieograniczone

5 Historisches Wörterbuch der Philosophie, Band 10, dz. cyt., 1442-1454.

6 „To, co religijne, nie zostaje nigdy zniweczone przez logikę, tylko zawsze przez to, że Bóg się wycofuje". M. Heidegger, Was heißt Denken, Gesamtausgabe, Band 8, red. von P.L. Coriando, Frankfurt am Main 2002, 12.

7 „Szukanie Transcendencji przez osobiste przeżycie, szukanie jej we „mnie” i przeze „mnie” wydaje się być najbardziej typowym sposobem bycia człowieka naszych czasów”. 
możliwości bycia w świecie. Otacza boskim kultem sobie podobnych. I nie rozumie, że może się to źle dla niego skończyć8.

"Jak powiada Jaspers: człowiek nie zawdzięcza sobie samemu swojej egzystencji. Człowiek jest podarowany sobie przez Transcendencję. To jest proste, ni mniej, ni więcej. Nie wyszukałem sobie swoich rodziców, nie określiłem czasu swojego urodzenia, nie wiem, kiedy umrę. Mam swoje życie, aby żyć i wystąpić przed tym, który dał mi ten podarunek. Nie mówię kiedyś wystąpić - przecież nie bierze się czasowości do grobu, bo w tym momencie jesteśmy poza czasem i przeszłością i przyszłością - w każdym razie mam tak wystąpić i tak żyć, żebym mógł się przed nim stawić, nie płonąc ze wstydu. To jest wszystko, czego mogę wymagać"9.

Filozofia zobowiązuje się do uzasadniania swojego myślenia, zwłaszcza tego, co w punkcie wyjścia zostaje uprzednio założone. Tylko oczywiste prawdy nie wymagają uzasadnienia. To, że „człowiek został sobie podarowany przez Transcendencję" jest prawdą, którą należy dopiero uzasadnić, nie tylko uzasadnić w teoretycznym rozważaniu, lecz w faktycznym egzystowaniu. Jeżeli rozumiemy, że nasze życie zostało nam dane jako coś darmowego, na co w żaden sposób nie zasłużyliśmy i czego nie wypracowaliśmy, to czujemy się niejako zobowiązani do wykazania, że warto było nas powołać do istnienia. Podarowane życie jest jak kredyt, który należy spłacić, z rosnącymi odsetkami, w miarę jak z niego czerpiemy. Uzasadniamy dane nam życie, wydobywając z niego większy sens, niż ma ono samo w sobie.

J. Polakova, Perspektive der Hoffnung. Transzendenzsuche in der Postmoderne, Paderborn-München-Wien-Zürich 2005, 34.

8 „Jesteśmy selfmade - bogami, którzy posłuszni są jeszcze tylko prawom fizyki i przed nikim nie muszą ponosić odpowiedzialności. I tak wyrządzamy chaos i zagładę wspólnie żyjącym z nami istotom i światu, który nas otacza, interesujemy się tylko własnymi wygodami i własnymi rozrywkami, a mimo to jesteśmy niezadowoleni. Czy istnieje coś bardziej niebezpiecznego, niż niezadowoleni i wolni od odpowiedzialności bogowie, którzy nie wiedzą, czego chcą?". Y.N. Harari, Eine kurze Geschichte der Menschheit, München 2013, 507.

9 V.E. Frankl, P. Lapide, Gottsuche und Sinnfrage. Ein Gespräch, München 2016, 138. 
To jest leitmotiv logoterapii: człowiek uznaje wagę swojego życia, widzi potrzebę uzasadnienia swojego życia, nadając mu sensowną postać. Uzasadnić swoje życie przez sensowne postępowanie nie oznacza: uczynić je godnym ocalenia w oczach Boga. Tylko sam Bóg może uznać życie za usprawiedliwione, zacierając ślady jego niedostatków, za które możemy się wstydzić.

Człowiek rozumie siebie przez Transcendencję. „Co więcej. Człowiek jest także w tej mierze człowiekiem, w jakiej rozumie siebie przez Transcendencję"10. Zrozumienie siebie jest jedną z najgłębszych potrzeb człowieka. Rozumieć siebie polega na tym, aby wiedzieć, co począć ze swoim życiem. Człowiek potrzebuje czegoś więcej, niż umiejętności rozporządzania swoim życiem - potrzebuje wiedzy, jak żyć, aby sensownie się spełniać. Bóg nie nadaje sensu życiu ludzkiemu, ale człowiek znajduje w sobie środki do sensownego życia, pochodzące od Boga. Rozumieć siebie przez Boga oznacza rozumieć siebie jako istotę, w której Bóg pozostawił ślady otwierające możliwości spełnienia się w sensownym egzystowaniu. $\mathrm{O}$ ile rozumiemy siebie przez Boga, o tyle jesteśmy ludzcy. Być człowiekiem znaczy podejmować sensowne decyzje. Miarą człowieczeństwa jest wypełnianie sensu. „Tylko w tej mierze, w jakiej człowiek wypełnia sens, w tej mierze urzeczywistnia on także siebie samego"11. Bóg Frankla jest Bogiem, który znajduje upodobanie w sensownym byciu. Bóg jest tam, gdzie padają sensowne decyzje. Im sensowniej żyje człowiek, chcąc przypodobać się Bogu, tym bardziej jest ludzki. Bezsens jest nieludzki.

„Istota ludzkiej egzystencji leży w jej samotranscendencji (Selbsttranszendenz). Być człowiekiem znaczy już od zawsze być skierowanym na coś albo na kogoś, być oddanym dziełu, któremu człowiek się poświęca, człowiekowi, którego kocha albo Bogu, któremu służy"12.

10 V.E. Frankl, Ärztliche Seelsorge, dz. cyt., 339.

11 Tenże, Der Mensch vor der Frage nach dem Sinn, München-Berlin 2015, 225.

12 Tenże, Ärztliche Seelsorge, dz. cyt., 54. 
Frankla homo transcendens nie wykracza poza granice, jakie stawia drugi człowiek i świat, ale poza granice własnego Ja. Człowiek transcendujący nie przekracza siebie, aby poszerzyć granice swojego panowania, lecz przekracza siebie, by poza swoimi granicami spotkać to, co inne, co może stać się dla niego czymś godnym poświęcenia. Według pewnej opowieści, sprawiedliwy dostał się po śmierci do innego świata i został najpierw wprowadzony do sali jadalnej, gdzie wokół stołu siedziało mnóstwo wychudzonych ludzi. Byli bliscy wygłodzenia, mimo że stół był suto zastawiony potrawami. Co się stało? Każdy z nich miał w ręku długą na trzy metry łyżkę, którą nie mógł sięgnąć do własnych ust, jedynie był w stanie nakarmić siedzącego naprzeciw sąsiada. Tego ci ludzie nie chcieli zrobić, woleli raczej się zagłodzić. Potem poprowadzono tego samego sprawiedliwego człowieka do innej sali, gdzie stał dokładnie taki sam stól, obficie zastawiony jedzeniem. Wokół niego siedziała grupa ludzi z takimi samymi długimi łyżkami, najedzonych, spokojnych, pogodnych. Jeden karmił drugiego. „To jest raj”, powiedział mu anioł „tam gdzie byłeś przedtem, to było piekło".

„Łyżka jest intencjonalnością, nieprawdaż. Nie możesz siebie samego intendować (intendieren), tylko możesz intendować coś, czym nie jesteś. Przez wzajemność możliwa jest ludzka egzystencja, ponieważ poprzez innego znowu, jeżeli tak mogę powiedzieć, możesz być przytranscendowany (antranszendiert)” 13 . „Eyżka” otwiera na świat, toruje drogę do świata i pozwala wrócić ze świata do siebie. Spotykając się z tym, co inne, człowiek nie wraca tą samą drogą do siebie. Droga do sensu jest zawsze drogą okrężną. Przez zapożyczone z filozofii (Duns Scotus, Brentano, Husserl) słowo intencjonalność (intentio - skierowanie, zamiar) Frankl rozumie człowieka jako istotę zdolną do skierowania się (intendowania) poza siebie, ze względu na coś innego. Człowiek nie musi być zamknięty w swoim świecie i oglądać w nim, jak w lustrze, swoje odbicie. Intencjonalność pokazuje, że

13 V.E. Frankl, P.Lapide, Gottsuche, dz. cyt., 85. 
otwarcie na świat i wychodzenie do świata jest możliwe, a poruszanie się $\mathrm{w}$ świecie nie musi być dziełem przypadku lub poddawaniem się losowi, ale zamierzonym wyborem. Wierzę, jeżeli przeżyłem coś godnego wiary. Mam poczucie sensu, kiedy urzeczywistniłem coś wartościowego. Bez samotranscendencji i intencjonalności nie można zrozumieć człowieka jako istoty poszukującej sensu. Ludzie z problemami psychicznymi, przeżywający kryzys sensu, mają zubożoną i zaburzoną zdolność do intencjonalnego kierowania się na coś innego niż oni sami i transcendowania poza swoje granice. Zadaniem logoterapii jest motywowanie chorego i zdrowego człowieka do przekraczania siebie w poszukiwaniu sensu. Udzielanie pomocy człowiekowi choremu w przyjęciu sensownej postawy wobec cierpienia, nazywa Frankl duszpasterstwem lekarskim (ärztliche Seelsorge).

Transcendowanie człowieka Frank1 rozumie jako: (1) wykraczanie poza siebie i (2) wkraczanie w głąb siebie. Człowiek transcenduje na zewnątrz siebie, gdzie napotyka rzeczy, ludzi, Boga, których przeżycie w świetle wartości wypełnia go sensem. Nieustannie wmawia się człowiekowi, że nie jest on tym, który sensownie kształtuje swoje życie, lecz jest ofiarą losu, uwarunkowań społecznych, psychologicznych i biologicznych. Dla Frankla natomiast człowiek jest obdarzony zdolnością, jest w świecie po to, aby przekraczać siebie, zapominać o sobie, tracić siebie z oczu w tym, że oddaje się rzeczom lub drugiemu, wypełniając się sensem. Przydawanie sobie znaczenia i uznanie ze strony innych $\mathrm{w}$ niczym nie zastąpi sensu pozyskanego $\mathrm{z}$ własnego życia. „Sens życia nie może być wymyślony, lecz odkryty" ${ }^{14}$. Człowiek poszukuje sensu, który może znaleźć w sobie i wydobyć go z siebie. „Życie jawi się jako bezwarunkowo sensowne, pozostaje sensowne - ma sens i zachowuje go - w każdych warunkach i okolicznościach"15. Przez oddanie się dziełu, Bogu, człowiekowi,

14 V.E. Frankl, Ärztliche Seelsorge, dz. cyt., 88.

15 Tenże, Theorie und Therapie der Neurosen. Einführung in Logotherapie und Existenzanalyse, München-Basel 2007, 20. 
ukryty w życiu sens zostaje odnaleziony, wydobyty i spełniony. Sens nie jest sprawą dobrego samopoczucia i komfortu psychicznego. „Poczucie bezpieczeństwa jest zdradą samotranscendencji, a szukanie równowagi psychicznej jest utratą samotranscendencji"16. Zaspokajanie potrzeb w celu uzyskania równowagi psychicznej, jest poruszaniem się w kole. Transcendowanie, inaczej niż homeostaza psychologiczna, otwiera człowieka ciągle na sens przez spotkanie tego, co inne, podtrzymuje nieustannie pragnienie sensu, który jest nie do zaspokojenia. Zaspokajanie potrzeb daje czasowe i powierzchowne zadowolenie. Oddanie się czemuś lub komuś wywołuje trwałe i głębokie poczucie sensu. W transcendowaniu kryje się rezygnacja z siebie, wystawianie siebie na ryzyko utraty siebie. Jeżeli kogoś słucham, muszę siebie zakwestionować. Sens nie polega na zachowaniu i pomnażaniu życia, ale na zatracie życia. Stracić życie, aby je odzyskać, jako sensowne. Od sensu życia do życia sensem - oto droga logoterapii Frankla.

\section{BÓG JAKO MOŻLIWOŚĆ PRZETRWANIA W KRYTYCZNYCH SYTUACJACH ŻYCIOWYCH}

$\mathrm{Na}$ pytanie, czy logoterapia jest psychoterapią religijną, to znaczy psychoterapią zakładającą wiarę w Boga, Frankl odpowiada: „Jeżeli chodzi o problematykę religii, to muszę wobec Pana podkreślić, że logoterapia jest terapią, a mianowicie psychoterapią, to znaczy psychiatryczną metodą leczenia - nawet jeżeli jest ona niekiedy stosowana także przez nie-psychiatrów. I jako taka jest ona podejściem świeckim. Jeżeli pyta mnie Pan, Panie Kreuzer, jako założyciela logoterapii, to zrozumie Pan, że muszę na to nalegać, a nie tylko przywiązywać do tego wartość, że logoterapię można zastosować każdemu pacjentowi, religijnemu jak i niereligijnemu. Co więcej, muszę nalegać na to, że może ona być równie dobrze wykonywana

16 V.E. Frankl, P. Lapide, Gottsuche, dz. cyt., 90. 
przez terapeutów agnostyków, jak i wierzących. Naturalnie zajmujemy się także z punktu widzenia logoterapii, lepiej powiedziawszy logoteorii, fenomenem religijności człowieka, ale jako fenomenem istotnie ludzkim. Tak więc może Pan zapytać w sposób uprawniony: "Jakie miejsce zajmuje fenomen religijności w życiu człowieka, w życiu duszy człowieka?« Ale nie może Pan zapytać. »Czy logoterapia wierzy w Pana Boga? « To jest pytanie nieuprawnione"17.

Bóg w logoterapii jest możliwością znalezienia sensu, a religia może oddziaływać na zdrowie człowieka psychoterapeutycznie i psychohigienicznie. Religia służy ostatecznie sensowi życia. Nie potrafimy powiedzieć, czym jest sens, ale rozumiemy, czym jest sens życia. Trzeba rozumieć sens życia, aby sensownie żyć. Pytanie o sens jest dla Frankla istotnym komponentem ludzkiej egzystencji. $\mathrm{Na}$ pytanie o sens nie da się odpowiedzieć ogólnie, każdy musi dla siebie znaleźć na nie odpowiedź. Sigmund Freud napisał w liście do Marie Bonaparte: „W momencie, kiedy pyta się o sens i wartość życia, jest się chorym"18. Choroby sugerowanej przez Freuda Frankl nie uważa za zachowanie patologiczne, ponieważ „tylko człowiek może postawić pytanie o sens, zakwestionować sens swojego ludzkiego bycia" ${ }^{19}$. Człowiek nie pyta o sens życia jedynie wtedy, kiedy jest ono zagrożone, dojrzewa lub kończy się. Możemy postawić nasze życie pod znakiem zapytania, gdy jego sensowność wydaje się nam wątpliwa. Pytamy o sens po to, aby życiem odpowiedzieć na to pytanie. Niezgodność faktycznego życia z wartościami prowadzi do kryzysu sensu, który Frankl nazywa, „cierpieniem na bezsens życia” (das Leiden am sinnlosen Leben). Cierpienie na bezsens życia jest nerwicą naszych czasów. „Każdy czas ma swoją nerwicę i każdy czas potrzebuje swojej psychoterapii" ${ }^{20}$. Logoterapia jest psychoterapeutyczną

17 V.E. Frankl, F. Kreuzer, Im Anfang war der Sinn. Von der Psychoanalyse zur Logotherapie. Ein Gespräch, Wien 1994, 14.

18 S. Freud, Briefe 1873 - 1939, Frankfurt am Main 1960, 429.

19 Tenże, Ärztliche Seelsorge, dz. cyt., 21.

20 Tenże, Der Mensch, dz. cyt., 141. 
odpowiedzią na neurotyczny kryzys sensu naszych czasów. Przejawem kryzysu sensu jest kryzys religii. Kryzys wiary w Boga zakorzeniony jest w kryzysie wiary w sens. Również za kryzysem życia duchowego, kryzysem humanizmu, a nawet humanistyki kryje się kryzys sensu. Życie ma zawsze sens i nie traci go w żadnych warunkach i okolicznościach. „Nie istnieją takie sytuacje życiowe, które byłyby rzeczywiście bezsensowne"21. Może się tylko wydawać, że życie straciło sens. Trudne sytuacje nie muszą nas pogrążać w kryzysie, ale - przeciwnie - mogą wzmocnić nasze poczucie sensu, ponieważ „im trudniejsze staje się życie, tym bardziej staje się sensowne”22. Poszukiwanie i znalezienie sensu, do którego należy więź z Bogiem, pomaga człowiekowi żyć i przeżyć nawet w sytuacjach krytycznych $i$ beznadziejnych. Czasami sens życia sprowadza się do czystego przetrzymania i przetrwania. „To znaczy, człowiek, który skierowany jest na jakiś sens, czując się zobowiązany i odczuwając odpowiedzialność wobec tego sensu, ktoś taki ma nieporównywalnie większe szanse przeżycia w sytuacjach ekstremalnych niż inny przeciętny człowiek. Oczywiście nie jest to warunek wystarczający, aby przeżyć, ale warunek konieczny. Wielu ludzi, którzy czuli to zobowiązanie, także w religijnym sensie, wobec Boga, i tak przecież w końcu zginęło. Lecz $\mathrm{w}$ innych podobnych okolicznościach, tacy ludzie zorientowani na sens mają nieporównywalnie większe szanse przeżycia"23.

W filmie Moulin Rouge pokazana jest scena, w której Toulouse-Lautrec chce sobie odebrać życie. Słychać już syczenie ulatniającego się gazu, gdy nagle spojrzenie jego pada na sztalugi, na jeden z jego obrazów, na którym zauważa błąd. Podnosi się, zatacza w kierunku obrazu, jednym pociągnięciem pędzla doprowadza wszystko do porządku i zakręca kurek z gazem. Depresję, impuls samobójczy przezwycięża tylko dzięki poświęceniu się pewnemu zadaniu.

21 Tenże, Der unbewußte Gott, dz. cyt., 76.

22 Tenże, Ärztliche Seelsorge, dz. cyt., 101.

23 Tenże, Im Anfang, dz. cyt., 27. 
„Rozumiemy mądrość, która przemawia ze słów Harveya Cushinga, największego neurochirurga wszechczasów: »Istnieje tylko jeden jedyny sposób, aby przetrzymać życie: mieć zawsze jakieś zadanie do wypełnienia«. Ja też rzadko widywałem tyle spiętrzonych stosów książek, czekających na opracowanie, jak na biurku wiedeńskiego profesora psychiatrii Josefa Berze, kiedy miał 90 lat"24.

W nerwicowym zaburzeniu psychicznym wykonanie prostych codziennych czynności może okazać się ważnym zadaniem, podtrzymującym przy życiu. Ludzie dotknięci nerwicą, przejawiająca się poczuciem zatraty sensu, często ulegają wrażeniu, że znajdują się w sytuacji ekstremalnej. Podobne wrażenie mogą odnieść ci, którym przyszło żyć w atmosferze przemocy i strachu. Wartość sensownego życia, także życia z Bogiem, sprawdza się na ogół wtedy, gdy życie znajdzie się w sytuacji zagrożenia. Więź z czymś, do czego przywiązuje się wartość, daje większe szanse przeżycia niż brak zakotwiczenia $\mathrm{w}$ sensownym gruncie. Bezsensowne działania człowieka, który utracił poczucie sensu wypływające $\mathrm{z}$ instynktownego zachowania życia i odrzucił źródło sensu, jakim jest tradycja, doprowadziły do stworzenia sytuacji zagrażającej unicestwieniu całej wspólnoty ludzkiej.

„Jeśli ludzkość miałaby przeżyć w tych krytycznych dziesięcioleciach, to będzie mogła tego dokonać tylko wtedy, jeżeli wcześniej czy później zjednoczy się przez wspólną wolę do wspólnego sensu, to znaczy odkryje wspólne zadania” ${ }^{25}$. „Wo aber Gefahr ist, wächst das Rettende auch" (Hölderlin) - tam, gdzie jest zagrożenie, tam wyrasta także ratunek. Kto dąży do sensu, potrafi w sytuacji zagrożenia zobaczyć możliwość ratunku. Tam, gdzie zagrożenie dotyczy fundamentu bycia, trzeba za wszelką cenę szukać możliwości ratunku, aby przetrwać. Zagrożenie może urosnąć do takich rozmiarów, że przetrwanie staje się samym w sobie celem i sensem życia pojedynczego człowieka i ludzkich wspólnot. Logoterapia uczy nas niestrudzenie

24 Tenże, Das Leiden am sinnlosem Leben, Freiburg im Breisgau 2015, 82.

25 Tenże, Im Anfang, dz. cyt., 27. 
poszukiwania sensu, zwłaszcza w sytuacji zagrożenia. Ktoś, kto szuka sensu dla swojego lokalnie zagrożonego życia, może zrozumieć sens wspólnego działania na rzecz globalnie zagrożonego życia. Można też zawsze jeszcze, nie widząc możliwości ratunku i możliwości zmiany nastawienia wobec zagrożenia, jak twierdzi mistrz Heidegger, przygotować się na ostateczne spotkanie z Bogiem² ${ }^{26}$.

\section{RELIGIA JAKO WIARA W SENS}

Frankl jest świadomy bliskości swojej terapii względem religii i problematycznej pozycji, jaką przyjmuje ona wobec psychologii zdystansowanej do religii. Czy jego logoterapia - leczenie przez sens - jest erzacem religii? „Celem psychoterapii jest uzdrowienie duszy (seelische Heilung), a celem religii jest zbawienie duszy (Seelenheil)"27. Logoterapia nie jest ukrytą opcją religijną. Cel logoterapii jest czysto światowy - zdrowie duszy. Zdrowa dusza to dusza wypełniona sensem i odporna na kryzys sensu. Religia może pomóc w budowaniu sensu życia, ale nie zastąpi samodzielnego poszukiwania sensu przez człowieka. Pytanie, jak ma się sensowne życie do zbawienia, nie należy do logoterapeutycznego myślenia o religii.

„Dla logoterapii religia jest i może być tylko przedmiotem - lecz nie stanowiskiem. Logoterapia musi poruszać się poza wiarą objawioną, a pytanie o sens rozpatrywać $z$ jednej strony poza teistycznym, a $z$ drugiej strony poza ateistycznym światopoglądem. Jeżeli logoterapia ujmuje fenomen wiary nie jako wiarę w Boga, lecz jako szeroko pojętą wiarę w sens, to jest rzeczą jak najbardziej uprawnioną, że ujmuje i zajmuje się ona fenomenem wiary. Logoterapia jest o tym

26 „Już tylko Bóg może nas uratować. Jedyną możliwość ratunku widzę w tym, aby w myśleniu i poezji przygotować gotowość na pojawienie się Boga lub na nieobecność Boga w zagładzie". Spiegel - Gespräch mit Martin Heidegger (23. September 1966), w: M. Heidegger, Reden und andere Zeugnisse eines Lebensweges, Gesamtausgabe, Band 16, red. von H. Heidegger, Frankfurt am Main 2000, 671.

27 V.E. Frankl, Das Leiden, dz. cyt., 99. 
tak samo przekonana, jak Albert Einstein, dla którego stawiać pytania o sens życia znaczy być religijnym"28.

Logoterapia zajmuje się człowiekiem poszukującym sensu. Poszukiwanie sensu przejawia się w byciu religijnym, to znaczy w praktykowaniu wiary czy wierzeń religijnych. Człowiek religijny wykracza poza instynktowne zachowanie życia i przetrwanie w codzienności, odwołuje się do pozaświatowych mocy, aby zrozumieć sens swojego bycia w świecie. Rozumienie podstaw swojej egzystencji jest czymś wspólnym zarówno dla człowieka religijnego, jak i dla człowieka poszukującego sensu. W tym kontekście Frankl cytuje chętnie Paula Tillicha: „Być religijnym znaczy z pasją stawiać pytanie o sens naszej egzystencji”29. Ludwig Wittgenstein, na którego powołuje się Frankl, wyraża się podobnie: „Wierzyć w Boga znaczy widzieć, że życie ma sens” ${ }^{30}$. Nie waha się też dodać: „Sens życia, to jest sens świata, możemy nazwać Bogiem" ${ }^{1}$. Czy wiara w sens i wiara w Boga mogą się ze sobą spotykać i krzyżować? Czy wiara w sens jest niejawną wiarą w Boga? Czy poszukiwanie sensu może zaprowadzić do Boga? Czy można wierzyć w sens i szukać sensu, nie będąc człowiekiem religijnym? „Znalezienie sensu jest możliwe niezależnie od tego, czy ktoś jest religijny, czy nie jest religijny"32. To, że ktoś szuka sensu, nie musi koniecznie oznaczać, że szuka Boga. Ale to, że ktoś szuka Boga zawsze oznacza, że szuka sensu. „Człowiek religijny może, ogólnie rzecz biorąc, prędzej albo, powiedzmy, łatwiej znaleźć sens niż człowiek niereligijny"33. Religijny człowiek, w odróżnieniu od człowieka niereligijnego, otwarty jest na wymiar transcendentny,

28 Tenże, Ärztliche Seelsorge, dz. cyt., 339.

29 P. Tillich, Die Verlorene Dimension in der Religion, w: Paul Tillich, Abenteuer des Geistes, Gütersloh 1961, 234.

30 L. Wittgenstein, Tagebücher 1914 - 1916, Frankfurt am Main 1989, 168.

31 Tamże, 167.

32 V.E. Frankl, Der unbewuße Gott, 66. Frankl powołuje się na przeprowadzone w Stanach Zjednoczonych liczne testy i ankiety, potwierdzające, że ludzie nie przyznający się do żadnego wyznania, wierzyli w sens i poszukiwali go w życiu.

33 Tenże, Im Anfang, dz. cyt., 38. 
gdzie może odkryć wartości, których urzeczywistnienie daje sensowne spełnienie.

Logoterapia mówi zarówno o wierze w Boga, jak i wierze w sens. Wiara w Boga i wiara w sens są transcendentne, to znaczy przekraczają granice ludzkiego myślenia. Przez wiarę zwykło się rozumieć przekonanie utrzymujące, że coś jest prawdziwe. Wiara w Boga wyraża przekonanie, że Bóg prawdziwie istnieje. Wiara w sens jest wyrazem przekonania, że sens naprawdę jest. O ile przez wiarę w Boga człowiek nadaje swojemu życiu nadprzyrodzony sens, o tyle wiara $\mathrm{w}$ sens pozwala wydobyć go z samego życia. Jeżeli celem wiary w Boga jest życie wieczne, to sens życia ziemskiego jest podporządkowany sensowi życia wiecznego. Sens życia ziemskiego jest rozumiany ze względu na sens życia wiecznego. Wiara w Boga może być jedną z możliwości sensownego życia, niezależnie od swojego zbawczego przeznaczenia. Wiara w Boga nie wyklucza się właściwie $\mathrm{z}$ wiarą w sens. Można wierzyć w Boga i w sens. Człowiek wierzący w Boga może popaść w kryzys sensu, w którego przezwyciężeniu może pomóc mu logoterapia, opierając się na jego wierze w sens. Człowiek żyjący wiarą w sens, poprzez wiarę w Boga, może wzmocnić sens swojego życia i lepiej przetrwać w kryzysie sensu. Wiara w sens wydaje się być bardziej źródłowa niż wiara w Boga. Kiedy człowiek utraci wiarę w Boga, może żyć dalej, jeżeli wierzy w sens. Kiedy straci wiarę w sens, nie ma po co żyć. Nie słyszy się raczej, żeby ktoś zrobił sobie krzywdę, straciwszy wiarę w Boga, ale znane są liczne przypadki samobójstw $z$ powodu utraty wiary w sens.

Frankl rozróżnia trzy znaczenia sensu: 1 . Sens w życiu (sens sytuacji) 2. Sens (u kresu) życia 3. Sens (nad-sens) całości (tego, co istnieje) ${ }^{34}$. Wiara w sens rozumiana jest przez Frankla jako wiara w „nad-sens”, „wiara we wszechobejmujący sens” ${ }^{35}$. Wiara w sens

34 K. Michalski, Poszukiwanie sensu według logoterapii i analizy egzystencji Viktora E. Frankla, Studia z Historii Filozofii 9(2018)2, 151.

35 V.E. Frankl, Ärztliche Seelsorge, dz. cyt., 340. 
może być $\mathrm{w}$ pewnym znaczeniu religią jako wiarą $\mathrm{w}$ pozaświatowe źródło mocy. „Religia, względnie wiara w sens, jak można by powiedzieć, jest radykalizacją "woli sensu«, o ile chodzi o »wolę ostatecznego sensu«, »wolę nad-sensu"”36. Radykalizacja (radix - korzeń) jest bezwzględnym, postępującym pójściem na granice na przykład myślenia i doświadczenia. Jeżeli religia jako wiara w sens jest radykalizacją woli ostatecznego sensu, to znaczy, że człowiek religijny, jako wierzący w sens, pragnie sensu w sposób coraz bardziej nieograniczony. Nic nie może powstrzymać człowieka radykalnie pragnącego sensu. Żadna przeszkoda nie może zachwiać wiarą w ostateczny sens. Wiara w sens jako religia polega na tym, aby „działać »jakoby« życie miało nieskończony »nad-sens«, wykraczający poza naszą skończoną zdolność ujmowania" ${ }^{37}$. Wiara w ostateczny sens jest czymś innym i czymś więcej niż wiara w racjonalny porządek świata, która jest źródłem radykalnego poszukiwania prawdy o świecie i postępu nauki. Jeżeli wiara w racjonalny porządek świata musi liczyć się z ograniczeniami, jakie stawia tajemnica życia, to wiara w ostateczny sens może czerpać z niekończącego się źródła sensu, odsłaniając tajemnicę życia. Nie można wykluczyć, że za wiarą jako wolą ostatecznego sensu kryje się jakaś boska siła, ponieważ „....) religijna wiara jest ostatecznie wiarą w Nadsens - zaufaniem do Nadsensu"38. Wielu ludzi pokazało $\mathrm{w}$ swoim życiu niezłomną wiarę w ostateczny sens, nie przyznając się do określonej wiary religijnej. „Religia daje się w rzeczywistości zdefiniować jako wypełnienie »woli ostatecznego sensu«"39. Normalnie człowiek chce sensu. To chcenie sensu staje się religią, kiedy człowiek pożąda sensu za wszelką cenę, do końca, bez względu na wszystko. Bycie religijnym, pokazuje się najwyraźniej, kiedy wypełnienie woli ostatecznego sensu decyduje o przeżyciu lub samozagładzie. Religia

36 Tamże, 341.

37 Tenże, Der unbewußte Gott, dz. cyt., 100.

38 Tenże, Das Leiden, dz. cyt., 104.

39 Tenże, Der unbewußte Gott, dz. cyt., 98. 
rozumiana jako wola ostatecznego sensu oznacza, że dążenie do sensu stoi ponad wszystkim, ponad szukaniem przyjemności i dążeniem do władzy. Wola sensu pcha człowieka dotkniętego nerwicą i zdrowego człowieka do zmiany tego, co uwikłało go w bezsensowne położenie lub do przyjęcia sensownego nastawienia wobec tego, co zachwiało sensem jego codziennego życia. Dzięki woli ostatecznego sensu, $\mathrm{w}$ imię przeżycia sensu, człowiek potrafi walczyć dla sprawy, która wydaje się być beznadziejna i z góry na straconej pozycji ${ }^{40}$.

Religia (religio - wiązanie, przestrzeganie) potocznie rozumiana, jest wiązaniem życia z Bogiem i wypełnianiem wymagań Boga, w oczekiwaniu na błogosławieństwo i nagrodę wieczną. Wiara w sens jako religia wiąże życie człowieka $\mathrm{z}$ dążeniem do sensu i stawia wymaganie wypełnienia nim życia przez urzeczywistnienie wartości. W każdej chwili człowiek musi wierzyć, że to, co robi, ma sens. Wiara $\mathrm{w}$ sens ostateczny podtrzymuje nasze działania i daje poczucie, że wszystkie sensowne poczynania idą wraz z nami i pozostają z nami, dopóki żyjemy. Wiara w sens ostateczny nie daje nadziei na życie wieczne, ale nadzieję na sensowne zakończenie życia ziemskiego. „Nadzieja nie jest przekonaniem, że wszystko dobrze się skończy, ale pewnością, że coś ma sens, obojętnie, jak się skończy" (Vaclav Havel). Wszystko dobre, co się sensownie kończy. Gdybyśmy byli zdeterminowani $\mathrm{w}$ dążeniu do sensu, nie musielibyśmy chodzić do psychiatry.

\section{SUMIENIE JAKO MIEJSCE PODEJMOWANIA SENSOWNYCH DECYZJI, ŹRÓDŁO POSZUKIWANIA SENSU I PRZESTRZEŃ ROZMOWY Z BOGIEM}

Transcendowanie nie jest tylko wychodzeniem na zewnątrz, poza swoje granice. Człowiek transcendujący może przekraczać wewnątrz

40 Marek Edelman, dowódca powstania w Getcie Warszawskim, powiedział kiedyś Franklowi, że dobrze wiedzieli o tym, iż podjęta walka nie ma żadnych szans powodzenia, ale wydawało im się bardziej sensowne zginąć z bronią w ręku niż w obozie. 
siebie granice swojej psychiki w kierunku tego, co duchowe, przechodząc z niższego psychicznego do wyższego duchowego bycia, gdzie natrafia na dwie możliwości wychodzenia i kierowania się ku Bogu: sumienie i zdolność do relacji z Bogiem. Zanurza się w siebie, aby wynurzyć się z nieznanymi możliwościami bycia. Transcendowanie w głąb siebie otwiera drogę do Boga po śladach, które zostały pozostawione przez Niego samego.

Psychoanaliza Freuda wyróżnia w człowieku sferę świadomego przeżywania i miejsce, gdzie występują nieświadome, niewiadomego pochodzenia, bezosobowe siły. Nieświadome siły popędowe rządzą świadomym życiem człowieka w sposób, o którym człowiekowi nawet się nie śniło ${ }^{41}$. Nieujarzmione, ukryte siły, będące źródłem pędu życiowego, zderzają się z tym, co człowiek jako nieprzyjemne, przykre i frustrujące wypiera w głąb siebie, gdzie stają się „materiałem”, który może wybuchnąć $w$ postaci nerwic $i$ innych niezdrowych zachowań. Frankl tylko do pewnego stopnia zgadza się Freudem w rozumieniu tego, co nieświadome. W nieświadomości Frankl widzi nie tylko źródło występowania pożądawczych sił, które mogą zdominować świadome życie człowieka, wymknąć się spod kontroli i obrócić się przeciw niemu. Odkrywa w niej też nieskażony obszar duchowych możliwości, dzięki którym człowiek może sensownie ukształtować swoje życie. „Duch jest niesiony przez to, co nieświadome”42. Władzą, która panuje w duchowej nieświadomości jest sumienie. W sumieniu rozgrywa się to, co jest rozstrzygające dla życia ludzkiego. „To, co nazywamy sumieniem sięga do nieświadomej głębi, jest zakorzenione w nieświadomym gruncie; wielkie, prawdziwe - egzystencjalnie prawdziwe - decyzje w ludzkim byciu dokonują się każdorazowo zupełnie nierefleksyjnie i tym samym także nieświadomie"43.

41 W snach widzi Freud królewską, to znaczy, najprostszą i najkrótszą drogę do nieświadomego życia.

42 V.E. Frankl, Logotherapie und Existenzanalyse, dz. cyt., 76.

43 Tenże, Der unbewußte Gott, dz. cyt., 23. 
Życie człowieka toczy się w sposób mniej lub bardziej świadomy. Nasze myślenie i działanie kierowane jest ukrytymi dążeniami, z których nie zawsze zdajemy sobie sprawę przy dokonywanych wyborach i podejmowanych decyzjach. Im ważniejsza życiowa decyzja, tym głębiej mogą tkwić ukryte dążenia, które wyznaczają i nadają jej sensowną postać. Nie jesteśmy w stanie dociec prawdziwego źródła wielu decyzji, które miały zdecydować o naszym losie. Dopiero po czasie możemy zrozumieć i uświadomić sobie sens decyzji, jakie w głębi serca, ale $z$ całym przekonaniem, kiedyś podjęliśmy. Ktoś na przykład podjął decyzję zostania architektem, aby wyrazić się w projektowaniu estetycznych budowli, zgodnych z otoczeniem i zrównoważonym rozwojem, nie uświadamiając sobie ukrytego pragnienia trwałego, bezpiecznego zamieszkania, niegodzenia się z przemijaniem i sprzeciwu wobec niszczenia i marnotrawstwa. W ciągu życia dopiero ujawni się, na ile podjęte decyzje zapadły z głębi serca i przyniosą sensowne spełnienie, albo odsłoni się rozziew między ukrytymi dążeniami a faktycznym życiem, dalekim od sensownego spełnienia.

Sumienie rozumiane jest potocznie jako władza rozstrzygania między dobrem a złem. W sumieniu człowiek czuje się wezwany do kierowania się tym, co dobre i sprzeciwiania się temu, co złe. W sumieniu budzi się poczucie winy, wywołane uleganiem złu i poczucie żalu z powodu zaniedbania czegoś dobrego. Źródłowa prawda o sumieniu wyraża się w stwierdzeniu „miej sumienie”. Najgorszym zarzutem, jaki można usłyszeć, to jest, że ktoś „nie ma sumienia”, czyli, że nawet nie bierze pod uwagę tego, co słuszne. Sumienie żyje, dopóki ma się wątpliwości. Daje o sobie znać nie tylko w opowiadaniu się za tym, co dobre i w tak zwanych wyrzutach sumienia, pojawiających się w konsekwencji dokonania złej decyzji, ale także wtedy, kiedy powiedzieliśmy trochę za dużo lub za mało, zrobiliśmy coś niestosownego, głupiego, nie na miejscu - jednym słowem, kiedy zachowaliśmy się bezsensownie. Innym razem możemy mieć świadomość „czystego” sumienia i poczucie spełnienia, bo zachowaliśmy się właściwie, mądrze, tak, jak trzeba - sensownie. 
„Sumienie należy do specyficznie ludzkich fenomenów. Pozwala się zdefiniować jako intuitywna zdolność do wytropienia jednorazowego i jedynego sensu, ukrytego w każdej sytuacji. Jednym słowem sumienie jest organem sensu"44. Życie składa się z sytuacji. Ciągle znajduję się $\mathrm{w}$ określonej sytuacji, kiedy jestem $\mathrm{z}$ innymi lub sam, kiedy znajduję się w swoim mieszkaniu lub w otwartej przestrzeni. Dla logoterapii, której chodzi zawsze o sens, nie jest bez znaczenia, jak się zachowuję. Jeżeli chcę sensowne żyć, muszę sensownie zachowywać się w każdej sytuacji, w jakiej się znajdę; muszę przyjąć sensowną postawę zarówno w okolicznościach życia codziennego, jak i w sytuacjach, w które zostaję włączony przez wydarzenia życiowe, zwłaszcza przez przeciwności losu. Wejście do parku wymaga ode mnie tak samo sensownego zachowania, jak doznanie niepowodzenia życiowego. Kiedy poruszam się tropem wskazanym przez sumienie, to „wiem”, jak sensownie się zachować. Sensowne zachowanie nie zależy od przeglądu sytuacji i czasu do namysłu, ale od mądrości serca. Jest ona czymś więcej niż empatią czy inteligencją emocjonalną, które mogą być częściowo wypracowane. Nie można mylić sensownego bycia z poprawnym zachowaniem, które sprawia tylko wrażenie właściwego, sensownego postępowania. Sytuacja zawsze wymaga ode mnie zachowania, które może okazać się sensowne lub bezsensowne. Tak jak wzrok jest organem patrzenia i wypatrywania, tak sumienie jest organem wyczuwającym charakter sytuacji i otwierającym przed człowiekiem możliwość sensownego zachowania. Sumienie jako organ sensu nie istnieje tylko po to, abyśmy po fakcie odkryli rozmiary spustoszenia, pozostawione po chybionym zachowaniu, ale przede wszystkim po to, aby poruszać do sensownego działania w sytuacji, w której się znaleźliśmy. Kierując się tropem wytyczonym przez sumienie, możemy w konkretnej sytuacji rozumieć, jak sensownie się zachować. W jednej jedynej sytuacji mamy do wypuszczenia tylko jedną jedyną strzałę. Możemy trafić z sensownym zachowaniem lub

44 Tenże, Der Mensch, dz. cyt., 156. 
chybić. Wszystko zależy od tego, na ile kierujemy się intuicją wskazującą na sens. Elisabeth Lukas porównuje sumienie do kompasu, którego igła, niezależnie od miejscowych okoliczności, skierowana jest zawsze ku biegunowi północnemu ${ }^{45}$. Jak kompas, który określa zawsze podstawowy kierunek poruszania się, podobnie sumienie wskazuje na jedyny i jednorazowy sens faktycznej sytuacji, możliwy do urzeczywistnienia w horyzoncie tego, co właściwe i niewłaściwe i w kontekście wartości.

Kiedy rozumiemy, że mamy sumienie, odnosimy wrażenie, że coś w nas i do nas mówi. Słyszymy głos sumienia, które podpowiada to, co dobre i przestrzega przed tym, co złe, ale także sprzyja podejmowaniu sensownych decyzji i unikaniu tego, co sprzeciwia się sensowi. Za nasze czyny możemy odpowiadać przed innymi - np. rodzicami, wychowawcami lub sądem. Przede wszystkim jednak za sens naszego postępowania odpowiadamy przed własnym sumieniem. Jest ono podstawową instancją, przed którą człowiek staje. Można uchylić się od odpowiedzialności prawnej, ale nie przechytrzy się głosu sumienia, które odezwie się z nieświadomej głębi. Dla logoterapii nie jest bez znaczenia, jak rozumiemy głos sumienia: czy jest on tylko głosem pochodzącym z naszej głębi, czy może jest głosem kogoś, kto przez nas do nas mówi. To, czy w głosie sumienia rozpoznaję jeszcze kogoś innego poza mną, zależy według Frankla od tego, jak dalece jestem „sługą swojego sumienia” (Knecht meines Gewissens), to znaczy, jak wnikliwie i konsekwentnie wsłuchuję się w głos własnego sumienia.

„Sługą sumienia mogę być dopiero wtedy, gdy w moim samorozumieniu, rozumiem sumienie właśnie od strony Transcendencji, jako fenomen transcendujący moje czyste bycie człowiekiem - i tym samym mnie samego, moją egzystencję"46. Na tym polega bycie człowiekiem religijnym, że w sumieniu słyszymy głos Boga i przed Bogiem odpowiadamy za sens swojego życia. Do posłuszeństwa

45 E. Lukas, Lehrbuch der Logotherapie. Menschenbild und Methoden, München 2006, 32. 46 V.E. Frankl, Der unbewußte Gott, dz. cyt., 39. 
sumieniu, w którym jesteśmy tubą (Sprachrohr) głosu Bożego, sprowadza się ostatecznie istota religijności. Chociaż mogę nie być do końca pewny, czy rzeczywiście słyszę w sumieniu głos Boga i czy to, co mi mówi sumienie jest prawdziwe, to nie mam lepszego wyjścia, jak orientować się według tego głosu i zgodnie z nim podjąć decyzję. Podejmując taką czy inną decyzję, której nie jestem całkowicie pewny, biorę na siebie ryzyko błądzenia, które należy do mojego skończonego bycia ludzkiego. Niepewność sumienia nie zawiesza zdolności do decydowania i nie zwalnia z odpowiedzialności za podejmowane decyzje. Każdy ma sumienie, ale nie każdy go słucha i nie każdy potrafi usłyszeć w nim głos Boga.

„Niereligijny człowiek jest tym, który nie rozpoznaje Transcendencji sumienia. Także człowiek niereligijny "ma« sumienie i odpowiedzialność. Ale nie pyta dalej - ani o Przed czym odpowiedzialności, ani o Skq̨d sumienia" ${ }^{47}$. Odpowiedzialność jest podstawową wartością, która dotyczy każdego człowieka. Bez brania na siebie odpowiedzialności nie ma życia sensownego. Uchylanie się od niej sprzeciwia się życiu. Kto naraża drugiego na utratę życia, pociągany jest do odpowiedzialności. Życiowe okoliczności mogą sprawić, że człowiek będzie się uginał pod jej ciężarem. Frankl był zawsze przeciwny tak zwanej odpowiedzialności zbiorowej, która relatywizuje i rozmywa odpowiedzialność indywidualną i sprzyja zrzucaniu jej na kogoś innego. Szeregowi obywatele są tak samo odpowiedzialni za swoje bezsensowne decyzje, jak ich wybrańcy, podejmujący na szeroką skalę decyzje sprzeczne z sensem. Odpowiedzialność wobec bliskich, współpracowników, społeczności, potomności jest nieporównywalnie różna od odpowiedzialności przed Bogiem, która nadaje większą wagę i powage podejmowanym decyzjom. Można żywić przekonanie, że o ile uniknie się odpowiedzialności za swoje czyny przed ludzkim trybunałem, to nie ucieknie się przed odpowiedzialnością wobec Boga. Tylko odpowiedzialne decyzje tworzą sens naszego

47 Tamże, 41. 
faktycznego życia. Świadomość obecności Boga może wzmocnić jakość podejmowania sensownych decyzji i ustrzec przed decydowaniem prowadzącym do pogrążania się w bezsensie ${ }^{48}$. „Działając na scenie życia, ale oślepiony przez pierwszoplanową codzienność, człowiek mimo to cały czas przeczuwa - z mądrości swojego serca obecność wielkiego, choć niewidzialnego Świadka i Widza, przed kim jest odpowiedzialny za wypełnienie konkretnego, osobistego sensu życia, którego się od niego wymaga"49.

Różne rzeczy moga przemawiać za istnieniem Boga w tym, co wewnątrzświatowe. Na różne sposoby usiłowano w dziejach myślenia religijnego wykazywać istnienie Boga przez to, co można zobaczyć w świecie, niezależnie od objawionej prawdy religijnej, która może stać się przedmiotem wiary. Wraz z postępem nauk i rozwojem filozofii przekonano się, że w świecie można odkryć nie mniej bezsensu i przypadku niż tego, co celowe i uporządkowane, z którego można by dedukować prawdę o istnieniu dobrego Boga. Zaczęto ostrożniej myśleć o pozyskaniu przekonania o Bogu z tego, co jest dostępne w świecie. Uznano, że ślady, które Bóg mógł pozostawić w świecie są ulotne, jak ślady na piasku i zaszyfrowane (Jaspers). Niczego nie dowodzą i mogą wskazywać lub nie wskazywać na boskie pochodzenie. Wszystko zależy od tego, na ile widzenie człowieka wspomagane jest wiarą. W filozofii i psychologii od dawna mówi się o możliwości poszukiwania śladów Boga nie w otaczającym nas świecie, ale w głębinach ludzkiej duszy. „Sumienie jako immanentno-psychologiczny fakt wskazuje (verweist) przez siebie na Transcendencję" ${ }^{50}$. Wielu filozofów: Augustyn, Descartes, Kant, Levinas i psychologów głębi: Erich Fromm, Carl Gustav Jung, Elisabeth Kübler-Ross, Karen Horney jest przekonanych, że gdzieś w głębi duszy człowiek może

48 Istnieją religie, które zdają się usypiać odpowiedzialność człowieka za sens swojego życia. 49 V.E. Frankl, Logotherapie und Existenzanalyse, dz. cyt., 113.

50 Tenże, Der unbewußte Gott, dz. cyt., 40. 
natrafić na pierwotny sens, którego pochodzenie wskazuje na Boga ${ }^{51}$. Do tej tradycji dołącza Frankl, który w ludzkiej głębi widzi nie tylko miejsce obecności nieokreślonych sił, mogących zachwiać dążeniem człowieka do sensu, ale źródło sensotwórczej dynamiki, wskazującej na Boga. Dzisiejszy człowiek nie ma zwyczaju zapuszczania się w głąb siebie. Porusza się po powierzchni swojego bycia. Dlatego trudno mu odkryć niewyczerpane źródło budowania sensu i tak łatwo ulega kryzysowi sensu.

Sumienie nie jest miejscem spotkania Boga, lecz tym, co umożliwia transcendowanie ze świata ku Bogu. Kto tylko w obrębie siebie szuka Boga, szybko może uwierzyć, że sam się nim stanie. W filozofii religii od jakiegoś czasu mówi się o Bogu poza Bogiem - to znaczy o człowieku, który kwestionuje Boga jako ostateczne odniesienie do wartości i sam kreuje siebie jako dyktatora wartościowania. Człowiek religijny, przeciwnie, w głębi swojego sumienia słyszy głos, wyprowadzający go na zewnątrz ku transcendentnemu Bogu. Jedynie Bóg, na spotkanie którego muszę wyjść poza swój świat, jest Bogiem, z którym mogę się po partnersku komunikować.

„Właściwie nie można mówić o Bogu, tylko do niego, nie o nim jako o rzeczy, o czymś, o czymś bezosobowym, o jakimś on. Możemy mówić tylko do niego jako do Partnera, do kogoś, do Ty" 52 . Mówić o Bogu w trzeciej osobie jest, jak usiłować mówić o kimś poza jego plecami, mając go przed sobą. Nie możemy stawiać żadnych warunków, tylko wszechstronnie nastawić się na pojawienie się Boga. Bóg nie jest przedmiotem myślenia. Bóg przychodzi na myśl, „Gott fällt ins Denken ein” (Heidegger), „Dieu vient a l'idee” (Levinas). Bóg może zjawić się w zasięgu naszego myślenia, kiedy przyjmujemy

51 W II wieku pisarz chrześcijański Tertulian był przekonany, że dusza ludzka jest z natury chrześcijańska, anima naturaliter christiana, to znaczy, objawione prawdy o oddaniu życia dla drugiego (miłość bliźniego), dla idei i dzieła ( w tym przypadku chrześcijaństwa), Boga - odpowiadają naturze człowieka, który chce się sensowne spełnić (w tym przypadku zbawić).

52 V.E. Frankl, Der unbewußte Gott, dz. cyt., 111. 
postawę czuwania. Prawdziwa teologia nie powstaje w gabinetach, ani na forach dyskusyjnych, ale na kolanach ${ }^{53}$. Kryterium prawdziwości myślenia o Bogu są zdarte kolana. Confessiones św. Augustyna są jedną wielką rozmową z Bogiem, kończącą się słowem „amen”. "Quaeram te, Domine, invocans te”: chcę Cię szukać, o Panie, wzywając Cię; „Proloquor in conspectu Dei mei”: Chcę mówić przed obliczem mojego Boga. Rozmowa z Bogiem jako partnerem musi pokonać różnicę, jaka występuje między byciem człowieka a byciem Boga, a jedocześnie jej nie zniweczyć. Na tym polega niezwykłość rozmowy z Bogiem, że Bóg jest zawsze kimś więcej i kimś innym niż tym, z którym rozmawiam. Ponieważ jest Bogiem, jest w mocy sprawić, że mogę rozmawiać z Nim, jak z kimś bliskim mojemu sposobowi myślenia.

„Bóg jest Partnerem naszych najbardziej intymnych rozmów ze sobą. To praktycznie oznacza: Kiedy tylko jesteśmy sami ze sobą, kiedy tylko prowadzimy rozmowę ze sobą w ostatecznej samotności i ostatecznej powadze, jest rzeczą uprawnioną, aby Partnera tych rozmów ze sobą nazwać Bogiem - niezależnie od tego, czy uważamy się za wierzących czy niewierzących" ${ }^{54}$. Człowiek może być samotny, bo nie może znaleźć towarzystwa, nie szuka go albo zostaje opuszczony przez kogoś, kto mu towarzyszył. Samotność niekoniecznie musi być tylko dołującym utrapieniem, paraliżującym życiowe poczynania. Kiedy człowiek jest sam, ma możliwość spojrzenia w głąb siebie i uznania, że jest zdany na samego siebie, że opiera się o granice własnego bycia. Bycie bez towarzystwa nie pozbawia człowieka możliwości mówienia. Wręcz przeciwnie, w samotności rośnie potrzeba mówienia, mówienia do siebie. Rozmowa ze sobą

53 Szwajcarski teolog Hans Urs von Balthasar odróżnia teologię klęczącą (die kniende Theologie) od teologii siedzącej (die sitzende Theologie). Tak zwana teologia siedząca, rozwija się w oderwaniu od modlitewnego i mistycznego doświadczenia, mniej więcej od późnej scholastyki i pokazuje upadanie myślenia o Bogu. H. Urs von Balthasar, Verbum caro: Skizzen zur Theologie I, Zürich, 1990.

54 V.E. Frankl, Der unbewußte Gott, dz. cyt., 96. 
może nie tylko świadczyć o ograniczonej zdolności do komunikacji lub braku możliwości komunikowania, ale może być postrzegana jako zdolność do zbierania i porządkowania myślenia. Samotna rozmowa nie jest „wygadaniem się" przed samym sobą. Dopiero w głębokiej samotności człowiek staje się na tyle poważny, że może mówić o rzeczach w najwyższym stopniu ważnych, które chce powierzyć nadludzkiej, boskiej istocie, niezależnie od tego, czy występuje ona w historycznej postaci Jezusa, czy w postaci wkraczającego w dzieje Boga Jahwe, czy w innej wyjątkowej postaci. Istotne jest, że może mówić do kogoś, kto ma osobowe rysy, a jednocześnie jest boską istotą. Człowiek najczęściej modli się, kiedy jest źle, aby odmienić lub znieść przeciwności losu. „Modlitwa jest dla mnie raczej przyjmowaniem, aby widzieć rzeczy w perspektywie, że mogą one mieć sens, mimo okropności”" Modlitwa jest pozostaniem z Bogiem, cokolwiek się dzieje, bo dopóki człowiek żyje, gra o życie może mieć swój sens. Modlitwa jest wyrazem wiary, której istota polega na byciu z Bogiem, bez względu na wszystko i mimo wszystko. Przez religijność Frankl rozumie religijność osobistą (persönliche Religiosität) - nie jakąś nieokreśloną, synkretyczną, ale indywidualnie wypracowaną religijność, zakorzenioną w tradycji, w której się wyrosło. Stoi ona ponad tradycjonalizmem religijnym, może oprzeć się instrumentalizacji politycznej i nie pozwala się stopić w jednorodną, ogólną świadomość religijną, łatwo narażającą się na zarzut bycia kolektywną nerwicą (kollektive Neurose, Freud) ${ }^{56}$.

55 Tamże, 128.

56 Religijne sekty i grupy religijne o cechach sekciarskich, słusznie narażają się na zarzut bycia kolektywną nerwicą, która pozbawia swoich wyznawców indywidualnego rozwijania swojej religijności. 


\section{UKRYTY BÓG JAKO MOŻLIWOŚĆ STWORZENIA WIĘZI RELIGIJNEJ}

Każdy człowiek w tym, co myśli i robi, kieruje się obrazem samego siebie. Przeważnie wydaje mu się, że jest kimś więcej. Ma wrażenie, że jest mądrzejszy, lepszy, sprawniejszy, ładniejszy. Dopiero w konfrontacji z życiem może boleśnie przekonać się, że jest inaczej. Myśleniu i byciu, kierującym się przerysowanym wyobrażeniem o sobie, towarzyszy zazwyczaj nieufność do ukrytych możliwości, dzięki którym można stać się istotnie kimś innym, kimś więcej niż się jest w rzeczywistości. Każdy, kto oddaje się sportom biegowym, wie, że jakość biegania rośnie w miarę, jak biega się coraz szybciej i coraz dalej. Dopiero podczas wzmagającego się wysiłku, można się przekonać o ukrytych w nas niepojętych siłach, jakie w nas siedzą. Franklowskie myślenie, zwłaszcza religijne, odwołuje się do ukrytych możliwości człowieka i do prawdy, że to, kim człowiek jest, wychodzi na jaw w sposobie decydowania.

„To, że człowiek może nie uświadamiać sobie moralności, znane jest od czasów Freuda, który powiedział, że człowiek często jest nie tylko o wiele bardziej niemoralny, niż myśli, ale także o wiele bardziej moralny, niż wierzy. Analiza egzystencji idzie teraz tylko o krok dalej, jeżeli reprezentuje pogląd, że człowiek jest także o wiele bardziej religijny niż przeczuwa" ${ }^{57}$. Pod pojęciem człowieka religijnego Frankl rozumie kogoś uznającego głos słyszany w sumieniu za głos Boga, kto przed Bogiem czuje się odpowiedzialny za sens swojego życia. Im wyższa świadomość religijna, tym bardziej człowiek jest posłuszny głosowi Boga w sumieniu i tym mocniej skłania się do podejmowania sensownych decyzji w obliczu Boga. Świadomość religijna podlega zróżnicowanemu natężeniu. Brak świadomości religijnej może oznaczać, że religijność nie została jeszcze uświadomiona, lub że została wyparta w nieświadome obszary ludzkiej duszy. „Ten sposób wierzenia jest, według nas, naprawdę nieświadomy, często w sensie

57 V.E. Frankl, Der unbewußte Gott, dz. cyt., 128. 
wypartej religijności"58. Człowiek może mieć rozmaite powody, by wyprzeć swoją religijność do nieświadomości, na przykład ze wstydu, ze względu na karierę, bo chce uchodzić za kogoś światopoglądowo niezależnego. Religijności nie da się zamknąć w nieświadomości, jak drzwi za sobą. W psychologii głębi mówi się o przepuszczalnej granicy między tym, co świadome i tym, co nieświadome. Nieustannie wypieramy coś do nieświadomości i uświadamiamy sobie coś, co się z niej wyłania. Nie można odciąć się od pamięci. Podobnie nie można odgrodzić się od nieświadomości. Wyparta do nieświadomości religijność ma możliwość przebicia się i przeniknięcia do świadomości człowieka. Może powrócić i wynurzyć się na powierzchni świadomości w przekręconej postaci. Patologiczne (karykaturalne, szydercze, kabaretowe, komercyjne) posługiwanie się treściami religijnymi jest niczym innym, jak objawem nieradzenia sobie z wypartą, ale nie dającą się usunąć, religijnością. ,Jego odniesienie do Transcendencji jest zaburzone. Jego transcendentna relacja jest wyparta. Lecz z ukrycia jego »transcendentnej nieświadomości« niekiedy daje o sobie znać ta wyparta Transcendencja w »niepokoju serca«, który czasami może prowadzić do wysuwającej się na czoło symptomatyki neurotycznej”59.

Istnieje niepokój zdrowy i niezdrowy. Niepokój przejawiający się w przyspieszonym tempie życia, wzrastającej mobilności, wzmagającej się codziennej nerwowości jest czymś typowym dla człowieka naszych czasów i przyczynia się do powstawania problemów psychicznych. Wewnętrzny niepokój towarzyszy nieodłącznie psychozom, nerwicom, depresjom i objawia się $\mathrm{w}$ postaci psychosomatycznych dolegliwości (zaburzenia snu, układu nerwowego, układu wegetatywnego). Niezależnie od niepokoju, który patologicznie drąży człowieka, tradycyjne religie mają potrzebę wzbudzać niepokój w sumieniach, aby bardziej skłonić swoich wyznawców do wierności religijnym i moralnym zasadom. Potrzeba dokonania czegoś wyjątkowego

58 Tamże, 114.

59 Tamże, 52. 
wyraża się w tak zwanym twórczym niepokoju. Sztuka i literatura mają ambicje „zaniepokoić” zanurzonego w codzienności człowieka i zwrócić jego uwagę na potrzeby świata. Czymś całkiem innym jest niepokój ludzkiego serca, którego nie da się ukoić przez żadne techniki relaksacyjne, środki uspokajające, ani tym bardziej przez środki odurzające. Heidegger mawiał: „Nietzsche i Hölderlin byli jedynymi wierzącymi w XIX wieku”. Nikt tak uporczywie jak oni, aż do pomieszania zmysłów, nie szukał sensu w tamtym stuleciu. Być może wszystkie niepokoje ludzkie, czasami przybierające postać choroby, zakorzenione są w mniej lub bardziej świadomym „niepokoju serca” poszukującego stałego lądu dla swojej egzystencji. „Inqietum est cor nostrum donec reqiescat in te” (Augustyn) - „niespokojne jest serce nasze, dopóki nie spocznie w Tobie".

Nieświadoma religijność świadczy, że człowiek nie utracił bezpowrotnie możliwości zawiązania relacji z Bogiem. Nieświadoma religijność daje o sobie znać, kiedy ludzie uchodzący za niewierzących, odczuwają wdzięczność wobec Boga, gdy spotka ich coś nieoczekiwanie dobrego lub odwołują się do niesprawiedliwości Bożej, gdy spotka ich nieszczęście. Doznanie czegoś przykrego jest czasami odbierane przez ludzi oficjalnie deklarujących się jako niewierzący za karę boską za domniemane niedobre czyny. Także troska o otaczający świat, o środowisko naturalne może być wyrazem nieuświadomionej religijności. Psychoterapeutyczna praktyka potwierdza występowanie snów o treści jednoznacznie religijnej u osób, które odcinały się od religijności. Nieświadoma religijność oznacza, że jest w nas ukryta zdolność do stworzenia relacji z Bogiem „Tego Boga nazywamy właśnie Bogiem nieświadomym”60. Określenie „nieświadomy Bóg” nie oznacza rzecz jasna, że Bóg jest nieświadomie w nas obecny, ale to, że możemy nie wiedzieć o istniejącej w nas możliwości zawiązania żywej więzi z Bogiem. Bóg w pewnym sensie mieszka w nas, ale my możemy sobie tego nie uświadamiać „To, co mówi nasza

60 Tamże. 
formuła o nieświadomym Bogu, to byłaby zakryta relacja człowieka do zakrytego ze swej strony Boga"61. W dziejach myślenia religijnego jest mowa o zakrytym Bogu, Deus absconditus: „Doprawdy, Ty jesteś Bogiem zakrytym” (Iz 41, 15). Apostoł Paweł, przemawiając na Aeropagu w Atenach, zwraca uwagę Grekom, że jeden z ołtarzy poświęcili „nieznanemu Bogu” (Dz 17, 23). Idea zakrytego Boga została szczególnie rozwinięta w myśleniu Cusanusa, Pascala, Calvina, Luthra, Levinasa. Myśl o ukrytym Bogu bliska jest przede wszystkim Augustynowi: „Tibi loquitur cor meum” - „moje serce rozmawiało już zawsze z Tobą". Religia jest świadomym byciem w obecności Boga. Jednym przychodzi to łatwo, niektórzy muszą sięgać w głąb siebie, aby poruszyć świadomość bycia przed Bogiem. Czasami dopiero krytyczna sytuacja życiowa może obudzić ukrytą możliwość budowania sensu życia wraz z Bogiem. Niekiedy trzeba po prostu "przeżyć swoje”, aby zrozumieć prawdę o ukrytym w nas Bogu. Wielu przez całe życie aż do końca nie ma potrzeby, aby pozwolić Bogu wyjść z ukrycia.

\section{RELIGIA POTRZEBUJE DYNAMIKI WIARY}

Człowiek kształtuje swoją religijność poprzez tradycję i wychowanie. Samym źródłem religijności jest dotknięcie nadprzyrodzonej siły, zwane łaską lub wybraństwem, spotykające się z wolną decyzją człowieka, który uznaje Boga za swego Pana i Zbawcę. Instytucje religijne żywią przekonanie, że przez wychowanie i kultywowanie tradycji religijnej można utrzymać wiarę w swoich wyznawcach. Przeżywają rozczarowanie i frustrację, kiedy tracą swoich wiernych, obarczając winą świat opanowany materializmem i konsumpcją, nie przyznając się przy tym do mało wiarygodnego i nieprzekonującego głoszenia prawd religijnych. Kiedyś usiłowano nakłaniać do wiary, uciekać się do gróźb, szantażu, obietnic. Dzisiejszy człowiek, pozostawiony

61 Tamże, 47. 
sobie samemu, staje się coraz bardziej religijnie obojętny nie przez to, że żyje w dobrobycie, komforcie, bezpieczeństwie, ale dlatego, że brakuje mu dynamiki wiary. Niekiedy jest tak, że nie potrafi wierzyć.

„Nie mogę przecież chcieć wierzyć - tak samo, jak nie mogę chcieć kochać, czyli zmusić się do miłości, i tak samo nie mogę się zmusić do nadziei wbrew własnemu przekonaniu. Istnieją rzeczy, których nie można pozostawić chceniu - i których nie można także przez to wywołać na żądanie lub na rozkaz. Przytoczę prosty przykład: Nie mogę na rozkaz się roześmiać. Jeżeli ktoś chce, abym się roześmiał, to musi się postarać, aby mi opowiedzieć dowcip"62.

Każda żywa istota ożywiana jest dynamiką, potrzebną do zachowania swojego życia. Potrzeba schronienia, pożywienia, bezpieczeństwa, wzrastania pobudza żywą istotę do dynamiki, zwanej biodynamiką. Zaspokojenie potrzeby bycia $\mathrm{z}$ innymi, bycia znaczącym, bycia uznanym, bycia twórczym potrzebuje dynamiki, nazywanej psychodynamiką. Dynamikę, która rodzi się z potrzeby ukształtowania swojego życia w sposób wartościowy, nazywa Frankl noodynamiką (nous - duch). Noodynamika budzi się z potrzeby bycia sensownym, bycia prawdziwym, bycia religijnym, bycia w harmonii ze sobą i ze światem. Czy dzisiejszy człowiek czuje jeszcze taką potrzebę? Co wtedy, kiedy braknie potrzeby bycia wartościowym? Nie możemy być ani optymistami, ani pesymistami, ale musimy być czujni. Nadciąga noc, trzeba przygotować się do czuwania.

\section{BIBLIOGRAFIA}

Batthyany A., Die Überwindung der Gleichgültigkeit. Sinnfindung in einer Zeit der Wandlung, Kösel, München 2017.

Böschemeyer U., Die Sinnfrage in der Psychotherapie und Theologie. Die Existenzanalyse und Logotherapie Viktor Frankls aus der theologischen Sicht, De Gruyter, Berlin 1977.

Fabry J., Das Ringen um Sinn, Paracelsus, Stuttgart 1973.

62 Tamże, 65. 
Fabry J., Wege zur Selbstfindung: wie man jedem Tag seinen Sinn gibt, Herder, Basel-Wien 1983.

Grom B., Religionspsychologie, Kösel, München 2007.

Harari Y.N., Eine kurze Geschichte der Menschheit, Pantheon, München 2013.

Frank1 V.E., Logotherapie und Existenzanalyse, Beltz, Weinheim-Basel 2010.

Frank1 V.E., Arztliche Seelsorge. Grundlagen der Logotherapie und Existenzanalyse. Mit den „Zehn Thesen über die Person”, Paul Zsolnay, Wien 2005.

Frank1 V.E., ... trotzdem ja zum Leben sagen. Ein Psychologe erlebt das Konzentrationslager, Kösel, München 2009.

Frank1 V.E., Die Psychotherapie in der Praxis. Eine kasuistische Einfübrung für Ärzte, Piper, München 1997.

Frankl V.E., Psychotherapy and Existentialism: Selected Papers on Logotherapy, Simon and Schuster, New York 1967.

Frank1 V.E., Psychotherapie für den Laien, Herder, Freiburg-Basel-Wien 1980.

Frankl V.E., Es kommt der Tag, da bist du frei. Unveröffentlichte Texte und Reden, Kösel, München 2015.

Frankl V.E., Grundkonzepte der Logotherapie, Facultas, Wien 2015.

Frankl V.E., Wer ein Warum zum Leben hat. Lebenssinn und Resilienz, Beltz, Weinheim-Basel 2017.

Frankl V.E., Der unbewußte Gott. Psychotherapie und Religion, Kösel, München 2017.

Frankl V.E., Theorie und Therapie der Neurosen. Einführung in Logotherapie und Existenzanalyse, Ernst Reinhardt, München-Basel 2007.

Frankl V.E., Der Wille zum Sinn, Hogrefe, Bern 2016.

Frank1 V.E., Der leidende Mensch. Anthropologische Grundlagen der Psychotherapie, Hans Huber, Bern 2005.

Frankl V.E., Das Leiden am sinnlosen Leben. Psychotherapie für heute, Herder, Freiburg im Breisgau 2009.

Frankl V.E., Der Mensch vor der Frage nach dem Sinn, Piper, München 2009.

Frankl V.E., Die Sinnfrage in der Psychotherapie, Piper, München 1997.

Frank1 V.E., Was nicht in meinen Büchern steht. Lebenserinnerungen, Beltz, Weinheim 2002.

Frank1 V.E., Bergerlebnis und Sinnerfahrung, Tyrolia, Innsbruck-Wien 2008.

Frankl V.E., Lapide P., Gottsuche und Sinnfrage, Gütersloher Verlagshaus, Gütersloh 2007.

Frankl V.E., Die Psychotherapie für den Alltag, Franz Deuticke, Wien 1982.

Frankl V.E., Kreuzer F., Im Anfang war der Sinn. Von der Psychoanalyse zur Logotherapie. Ein Gespräch, Franz Deuticke Verlag, Wien 1982. 
Freud S., Briefe 1873 - 1939, red. E.L. Freud, S. Fischer, Frankfurt am Main 1960. Heidegger M., Was heißt Denken. Gesamtausgabe, Band 8, red. F.-W. von Herrmann, Vittorio Klostermann, Frankfurt am Main 2002.

Historisches Wörterbuch der Philosophie, red. von J. Ritter, K. Gründer, Band 5, Basel-Stuttgart 1980.

Längle A., Viktor Frankl - eine Begegnung, Facultas, Wien 2013.

Längle A., Sinnvoll leben. Eine praktische Anleitung der Logotherapie, Residenz, St. Pölten-Salzburg 2007.

Lukas E., Von der Tiefenpsychologie zur Höhenpsychologie. Logotherapie in Beratunsgpraxis, Herder, Freiburg im Breisgau 1983.

Lukas E., Lehrbuch der Logotherapie. Menschenbild und Methoden, Profil, München 2006.

Lukas E., Der Schüssel zu einem sinnvollen Leben. Die Höhenpsychologie Viktor E. Frankls, Kösel, München 2011.

Lukas E., Auch das Leben hat Sinn. Logotherapeutische Wege zur Gesundung, Herder, Freiburg 1980.

Lukas E., Viktor E. Frankl. Arzt und Philosoph, Profil, München 2005.

Lukas E., Logotherapeutische Antworten auf die existentielle Fragen, Profil, München 2004.

Kolbe C., Heilung oder Hindernis. Religion bei Freud, Adler, Fromm, Jung und Frankl, Kreuz Stuttgart 1986.

Michalski K., Sens w logoterapii i analizie egzystencji Viktora E. Frankla, Kwartalnik Filozoficzny 45(2017)3, 105-131.

Michalski K., Poszukiwanie sensu wedtug logoterapii i analizy egzystencji Viktora E. Frankla, Studia z Historii Filozofii 9(2018)2, 143-170.

Polakova J., Perspektive der Hoffnung. Transzendenzsuche in der Postmoderne, Ferdinand Schöningh, Padernborn-München-Wien-Zürich 2005.

Psychiatrie in Darstellungen, red. L.J. Pongratz, Hans Huber, Bern-Stuttgart-Wien 1973.

Raskob H., Die Existenzanalyse und Logotherapie Frankls, Springer, München 2006. Richter H.-E., Hoffnung auf einen neuen Weg sich selbst und andere zu befreien, Rowohlt, Hamburg 1995.

Utsch M., Bonelli R., Pfeifer S., Psychotherapie und Spiritualität. Mit existentiellen Transzendenzfragen profesionell umgehen, Springer, Berlin 2014.

Viktor Frankl und die Philosophie, red. D. Battyany, O. Zsok, Springer, Wien-New York 2005. 


\title{
MEANING AND GOD. RELIGION IN VIKTOR E. FRANKL'S LOGOTHERAPY
}

\begin{abstract}
Today the question of meaning is not only one of the greatest themes in philosophy, but also in modern literature and art as well as in psychology. Viktor E. Frankl has founded a therapeutic direction called logotherapy within the framework of meaningoriented psychotherapy. The question of the meaning of existence in logotherapy includes the question of God. According to Frankl, God is one way to make life meaningful. Man is ultimately responsible for the meaning of his life before God. In the spiritual unconsciousness of man there is a hidden possibility to develop a relation with God. Frankl calls it "the unconscious God". People who are going through a life crisis have a better chance of surviving if they believe in God.
\end{abstract}

Frankl says that not only psychiatrists, but every doctor is obliged to assist patients with spiritual help.

Keywords: logotherapy, psychotherapy, Frankl, meaning, religion, faith

\author{
KAROL MICHALSKI \\ k.michalski@aon.at \\ Uniwersytet Opolski, Instytut Filozofii \\ ul. Strzelców Bytomskich 2, 45-084 Opole \\ ORCID: 0000-0001-9815-4750
}

DOI: 10.21697/spch.2020.56.2.03 